\title{
MODEL PEMBELAJARAN COOPERATIF LEARNING JIGSAW UNTUK MENINGKATKAN HASIL BELAJAR IPS GEOGRAFI MATERI MENGIDENTIFIKASI BERBAGAI PENYAKIT SOSIAL SEBAGAI AKIBAT PENYIMPANGAN SOSIAL DALAM KELUARGA DAN MASYARAKAT PADA SISWA KELAS VIII B SMP NEGERI 6 SUKOHARJO SEMESTER I TAHUN PELAJARAN 2017/2018
}

\author{
Sri Hartini \\ SMP Negeri 6 Sukoharjo, Jawa Tengah \\ Email: srihartini@gmail.com
}

\begin{abstract}
Abstrak: Penelitian ini bertujuan untuk meningkatkan hasil belajar IPS Geografi materi mengidentifikasi berbagai penyakit sosial sebagai akibat penyimpangan sosial dalam keluarga dan masyarakat melalui model pembelajaran Cooperative Learning Jigsaw pada siswa kelas VIII B SMP Negeri 6 Sukoharjo Semester I Tahun Pelajaran 2017/2018. Metode penelitian menggunakan Penelitian Tindakan Kelas yang dilaksanakan dalam dua siklus setiap siklus terdiri dua kali pertemuan, dengan empat tahap penelitian: perencanaan, pelaksanaan, pengamatan dan refleksi. Subjek penelitian ini adalah siswa-siswi kelas VIII B SMP Negeri 6 Sukoharjo tahun ajaran 2017/2018. Dengan jumlah 22 siswa. Teknik pengumpulan data yang digunakan adalah observasi, wawancara, tes, dan dokumentasi. Analisis data yang digunakan dalam penelitian ini adalah analisis deskriptif kualitatif. Hasil penelitian ini adalah meningkatkan hasil belajar IPS Geografi materi mengidentifikasi berbagai penyakit sosial sebagai akibat penyimpangan sosial dalam keluarga dan masyarakat. Hal ini dibuktikan dengan peningkatan hasil belajar siswa pada siklus I siswa yang berhasil mendapat nilai KKM, meningkat menjadi 14 siswa atau 63,63\% atau terdapat peningkatan sebesar 9,09\%. Sedangkan pada siklus II meningkat menjadi 18 siswa yang mendapat nilai diatas KKM atau $81,81 \%$ atau terdapat peningkatan sebesar $18,18 \%$ dari sebelumnya. Berdasarkan hasil penelitian ini dapat disimpulkan bahwa dengan penerapan model pembelajaran Cooperatif Learning Jigsaw dapat meningkatkan hasil belajar IPS Geografi materi mengidentifikasi berbagai penyakit sosial sebagai akibat penyimpangan sosial dalam keluarga dan masyarakat pada siswa kelas VIII B SMP Negeri 6 Sukoharjo Tahun Pelajaran 2017/2018.
\end{abstract}

Kata Kunci: hasil belajar, IPS Geografi, penyakit sosial, Jigsaw

\begin{abstract}
This study aims to improve the learning outcomes of IPS Geography material to identify various social diseases as a result of social deviation in the family and community through the model of Cooperative Learning Jigsaw learning in students of class VIII B Junior High School 6 Sukoharjo Semester I Lesson 2017/2018. The research method using Classroom Action Research which is carried out in two cycles each cycle consists of two meetings, with four stages of research: planning, implementation, observation and reflection. The subject of this research is the students of class VIII B SMP Negeri 6 Sukoharjo academic year 2017/2018. With a total of 22 students. Data collection techniques used are observation, interviews, tests, and documentation. Data analysis used in this research is descriptive qualitative analysis. The results of this study is to improve the learning outcomes
\end{abstract}


of IPS Geography material identifies various social ills as a result of social deviations in the family and community. This is evidenced by the increase in student learning outcomes in the first cycle students who managed to get the value of KKM, increased to 14 students or $63.63 \%$ or an increase of $9.09 \%$. While in cycle II increased to 18 students who got the value above the KKM or $81.81 \%$ or an increase of $18.18 \%$ from the previous. Based on the results of this study can be concluded that with the implementation of Cooperative Learning Jigsaw learning model can improve the learning outcomes IPS Geography material identify various social diseases as a result of social deviation in the family and society in students of class VIII B SMP Negeri 6 Sukoharjo Lesson 2017/2018.

Keywords: learning outcomes, geography IPS, social ills, Jigsaw

\section{PENDAHULUAN}

Pendidikan merupakan suatu aspek kehidupan yang sangat mendasar bagi pembangunan bangsa. Penyelenggaraan pendidikan di sekolah melibatkan guru sebagai pendidik dan siswa sebagai peserta didik. Hal tersebut diwujudkan dengan adanya interaksi belajar mengajar atau proses pembelajaran. Proses pembelajaran yang dilakukan oleh banyak tenaga pendidik saat ini cenderung pada pencapaian target materi kurikulum atau lebih mementingkan pada penghafalan konsep bukan pada pemahaman. Hal ini dapat dilihat dari kegiatan pembelajaran di dalam kelas yang selalu didominasi oleh guru. Dalam penyampaian materi, biasanya guru menggunakanmodel ceramah, di mana siswa hanya duduk, mencatat, dan mendengarkan apa yang disampaikannya dan sedikit peluang bagi siswa untuk bertanya.

Pembelajaran biasanya hanya disampaikan secara konvensional, dimana guru yang berperan aktif, sementara siswa cenderung pasif. Sikap siswa yang pasif dapat mengurangi keterlibatannya dalam mengikuti proses pembelajaran yang dapat mengakibatkan turunnya minat siswa dalam mengikuti proses pembelajaran. Masalah lain yang muncul adalah rendahnya kemampuan sosial antar siswa. Rendahnya rasa sosial ini akan menimbulkan sifat individualisme pada diri siswa. Hal ini sangat tidak baik jika terus menerus ada di dalam diri siswa. Oleh karena itu guru harus berperan aktif untuk menumbuhkan rasa sosial di antara siswa. Karena dengan tingginya kemampuan sosial yang dimiliki, para siswa akan lebih mudah berbaur di dalam lingkungan hidupnya.

Dalam hal lain yang dapat dikatakan masalah adalah kurangnya rasa percaya diri dalam diri siswa untuk mengemukakan pendapat dan berbicara di depan umum. Banyak siswa yang lebih memilih untuk memendam pendapatnya selama proses pembelajaran. Sebagai pengajar, guru harus membantu siswa menggali kepercayaan diri mereka. Karena dengan adanya rasa percaya diri, siswa akan lebih yakin untuk berbicara di hadapan orang. Hasil belajar siswa sangat dipengaruhi oleh kualitas pembelajaran yang dilaksanakan di sekolah. Salah satu yang menentukan kualitas pembelajaran adalah penggunaan model pembelajaran yang tepat dengan materi yang diajarkan. Pada kenyataannya banyak sekolah 
yang kurang memperlihatkan penggunaan model pembelajaran dalam setiap penampilan mengajar.

Dengan demikian, suasana pembelajaran menjadi tidak kondusif sehingga siswa menjadi pasif. Kenyataan ini berlaku untuk semua mata pelajaran termasuk mata pelajaran Ilmu Pengetahuan Sosial (IPS). Sardjiyo, dkk mengemukakan, "Ilmu Pengetahuan Sosial (IPS) adalah bidang studi yang mempelajari, menelaah, menganalisis gejala dan masalah sosial di masyarakat dengan meninjau dari berbagai aspek kehidupan atau satu perpaduan" (2010: 1.26).

Berdasarkan pendapat di atas dapat disimpulkan bahwa Ilmu Pengetahuan Sosial (IPS) adalah mata pelajaran yang mempelajari kehidupan sosial yang mengkaji seperangkat peristiwa, fakta, konsep, dan generalisasi yang berkaitan dengan isu sosial. Disamping itu, Ilmu Pengetahuan Sosial (IPS) juga merupakan salah satu bidang yang rumit karena luasnya ruang lingkup dan merupakan gabungan dari sejumlah disiplin ilmu seperti ekonomi, sejarah, antropologi, sosiologi, geografi, politik, hukum, budaya dan apa saja yang disebut sipil perlu ditekankan. Adapun tujuan dari Mata pelajaranIlmu Pengetahuan Sosial (IPS) adalah agar peserta didik memiliki kemampuan sebagai berikut: 1) Mengenal konsep-konsep yang berkaitan dengan kehidupan masyarakat dan lingkungan. 2) Memiliki kemampuan dasar untuk berfikir logis dan kritis, menumbuhkan rasa ingin tahu, mampu memecahkan masalah, dan memiliki ketrampilan dalam kehidupan sosial. 3) Memiliki komitmen dan kesadaran terhadap nilai-nilai sosial dan kemanusiaan. 4) Memiliki kemampuan berkomunikasi, bekerja sama dan berkompetensi dalam masyarakat yang majemuk, di tingkat lokal, nasional maupun global.

Upaya peningkatan prestasi belajar siswa tidak terlepas dari berbagai faktor yang mempengaruhinya. Dalam hal ini, diperlukan guru kreatif yang dapat membuat pembelajaran menjadi lebih menarik dan disukai oleh pesertadidik. Suasana kelas perlu direncanakan dan dibangun sedemikian rupa dengan menggunakan model pembelajaran yang tepat agar siswa dapat memperoleh kesempatan untuk berinteraksi satu sama lain sehingga pada gilirannya dapat diperoleh prestasi belajar yang optimal. Untuk itu perlu disadari oleh guru bahwa dalam melaksanakan pembelajaran perlu pula diupayakan pembelajaran yang bersifat membangun dan memberikan pengalaman terhadap materimateri yang diberikan.

Keterbatasan waktu yang tersedia menyebabkan guru mengejar target pencapaian kurikulum memilih jalan yang termudah untuk menginformasikan fakta dan konsep, yaitu melaluimodel ceramah kemudian latihan soal dan siswa memperhatikan penjelasan guru tanpa melakukan aktivitas sehingga siswa pasif. Guru dalam mengajarkan Ilmu Pengetahuan Sosial (IPS) khususnya sub pokok bahasan berbagai penyakit sosial sebagai akibat penyimpangan sosial dalam keluarga dan masyarakat kepada siswa kurang melibatkan siswa secara aktif dalam interaksi belajar mengajar sehingga siswa kurang termotivasi dalam belajar. Guru juga kurang melibatkan lingkungan sebagai media sehingga siswa kurang mengenal lingkungan dan tidak dapat memperoleh pemahaman yang berarti. Disaat proses belajar mengajar berlangsung, guru kurang menggunakan model pembelajaran yang 
bervariasi sehingga hal tersebut dapat menyebabkan siswa jenuh dan kurang aktif. Guru beranggapan sulit menerapkan model pembelajaran misalnya untuk materi geografi.

Penggunaan berbagai macam model pembelajaran dapat memakan waktu yang lebih lama sementara waktu mengajarnya terbatas. Guru juga jarang sekali menggunakan pendekatan pembelajaran ketika sedang mengajarkan materi Ilmu Pengetahuan Sosial (IPS). Terkait belum optimalnya proses pembelajaran Ilmu Pengetahuan Sosial (IPS) di kelas VIII B SMP Negeri 6 Sukoharjo, maka peneliti berupaya untuk menerapkan model pembelajaran Cooperative Learning Jigsaw sebagai salah satu alternatif pembelajaran bermakna yang bermuara pada pembelajaran yang aktif, kreatif, efektif dan menyenangkan.

Teori yang melandasi pembelajaran kooperatif jigsaw adalah teori konstruktivitas. Pada dasarnya pendekatan teori konstruktifisme dalam belajar adalah suatu pendekatan di mana siswa secara individu menemukan dan mentransformasikan informasi yang kompleks, memeriksa informasi sesuai dengan ketentuan dan merivisinya jika perlu (Soejadi dalam teti sobri, 2006.15). Secara etimologi Jigsaw berasal dari bahasa Inggris yaitu gergaji ukur dan ada juga yang menyebut dengan istilah Fuzzle, yaitu sebuah teka-teki yang menyusun potongan gambar. Pembelajaran kooperatif model Jigsaw, mengambil pola cara bekerja sebuah gergaji (jigsaw), yaitu siswa melakukan sesuatu kegiatan belajar dengan cara bekerja sama dengan siswa lain untuk mencapai tujuan bersama.

\section{KAJIAN TEORI}

\section{Teori Hasil Belajar Siswa}

Menurut R. Gagne seperti yang dikutip oleh Slameto (2000:78) memberikan dua definisi belajar, yaitu belajar adalah suatu proses untuk memperoleh motivasi dalam pengetahuan, keterampilan, kebiasaan, dan tingkah laku. Belajar adalah penguasaan pengetahuan atau keterampilan yang diperoleh dari instruksi. Menurut Skinner yang dikutip oleh Dimyati dan Mudjiono (2006:93) bahwa belajar merupakan hubungan antara stimulus dan respon yang tercipta melalui proses tingkah laku. M. Sobry Sutikno (2010:35) mengemukakan belajar merupakan suatu proses usaha yang dilakukan oleh seseorang untuk memperoleh suatu perubahan yang baru sebagai hasil pengalamannya sendiri dalam interaksi dengan lingkungannya.

Berdasarkan beberapa pengertian di atas maka dapat penulis simpulkan bahwa belajar adalah perubahan serta peningkatan kualitas dan kuantitas tingkah laku seseorang di berbagai bidang yang terjadi akibat interaksi terus menerus dengan lingkungannya.

Hasil belajar siswa menurut W. Winkel (2004:82) adalah keberhasilan yang dicapai oleh siswa, yakni prestasi belajar siswa di sekolah yang mewujudkan dalam bentuk angka. Hasil belajar adalah pola-pola perbuatan, nilai-nilai, pengertian-pengertian, sikap-sikap, apresiasi dan keterampilan-keterampilan (Suprijono, 2011:5). Hasil belajar adalah hasil yang dicapai dalam bentuk angka atau skor setelah tes hasil belajar pada setiap akhir pembelajaran (Dimyati dan Mujiono, 2006:24).

Definisi di atas dapat disimpulkan bahwa hasil belajar adalah prestasi belajar yang dicapai siswa dalam proses kegiatan belajar mengajar dengan membawa suatu perubahan 
dan pembentukan tingkah laku seseorang. Untuk menyatakan bahwa suatu proses belajar dapat dikatakan berhasil, setiap guru memiliki pandangan masing-masing sejalan dengan filsafatnya. Namun untuk menyamakan persepsi sebaiknya kita berpedoman pada kurikulum yang berlaku saat ini yang telah disempurnakan, antara lain bahwa suatu proses belajar mengajar tentang suatu bahan pembelajaran dinyatakan berhasil apabila tujuan pembelajaran khususnya dapat dicapai.

Dalam rangka mengetahui tercapai tidaknya tujuan pembelajaran khusus, guru perlu mengadakan tes formatif pada setiap menyajikan suatu bahasan kepada siswa. Penilaian formatif ini untuk mengetahui sejauh mana siswa telah menguasai tujuan pembelajaran khusus yang ingin dicapai. Fungsi penelitian ini adalah untuk memberikan umpan balik pada guru dalam rangka memperbaiki proses belajar mengajar dan melaksanakan program remedial bagi siswa yang belum berhasil. Karena itulah, suatu proses belajar mengajar dinyatakan berhasil apabila hasilnya memenuhi tujuan pembelajaran khusus dari bahan tersebut.

Hasil belajar yang dicapai oleh siswa di sekolah merupakan salah satu ukuran terhadap penguasaan materi pelajaran yang disampaikan. Peran guru dalam menyampaikan materi pelajaran dapat mempengaruhi hasil belajar siswa. Faktor-faktor yang mempengaruhi hasil belajar siswa penting sekali untuk diketahui, artinya dalam rangka membantu siswa mencapai hasil belajar yang seoptimal mungkin. Hasil belajar akan semakin maksimal jika semua unsur masyarakat menyadari pentingnya pendidikan, karena pendidikan cara perbaik memperbarui kualitas bangsa (Tho'in, 2017).

Hasil belajar yang dicapai siswa dipengaruhi oleh dua faktor baik yang bersifat mendorong atau menghambat, demikian pula dalam belajar. Faktor yang mempengaruhi prestasi atau hasil belajar siswa yakni faktor dari dalam diri siswa (interen) dan faktor yang datang dari luar (eksteren). Ahmadi (1998:72) mengemukakan untuk mencapai prestasi belajar siswa sebagaimana yang diharapkan, maka perlu diperhatikan beberapa faktor yang mempengaruhinya antara lain faktor yang terdapat dalam diri siswa (faktor intern) dan faktor yang berasal dari luar diri siswa (faktor ekstern).

\section{Penyakit Sosial}

G. Kartasaputra mendefinisikan bahwa perilaku penyimpangan adalah suatu tindakan yang dilakukan oleh seseorang atau sekelompok orang, yang tidak sesuai atau tidak menyesuaikan diri dengan norma-norma yang berlaku di masyarakat, baik yang dilakukan secara sadar ataupun tidak. Bentuk-bentuk penyimpangan tersebut, apabila terus berkembang akan menyebabkan timbulnya penyakit sosial dalam masyarakat. Dengan kata lain, penyakit sosial adalah bentuk penyimpangan terhadap norma masyarakat yang dilakukan secara terus-menerus. Sama halnya dengan penyakit-penyakit fisik pada umumnya, penyakit sosial pun tidak muncul secara seketika. Ada beberapa faktor yang menyebabkan timbulnya penyakit sosial di masyarakat kita. Faktor-faktor tersebut antara lain: 
1. Tidak adanya figur yang bisa dijadikan teladan dalam memahami dan menerapkan norma-norma yang berlaku di masyarakat. Dengan demikian, apa yang dirasa benar, akan dilakukan terus-menerus tanpa memedulikan apakah hal itu melanggar norma atau tidak.

2. Pengaruh lingkungan kehidupan sosial yang tidak baik. Lingkungan yang sebagian besar masyarakatnya sering melakukan tindak penyimpangan, seperti prostitusi, perjudian, dan mabuk-mabukan, bisa memengaruhi kondisi masyarakat yang tinggal di daerah itu, sehingga warganya ikut terjangkit penyakit sosial serupa.

3. Proses sosialisasi yang negatif. Seseorang yang bergaul dengan para pelaku penyimpangan sosial, seperti kelompok preman, pemabuk, penjudi, dan sebagainya, lambat laun akan menjadi sama dengan teman-teman sekelompok dengannya.

4. Ketidakadilan. Seseorang yang mendapatkan perlakuan tidak adil, bisa memicunya untuk melakukan protes, unjuk rasa, bahkan bisa menjurus ke tindakan anarkis.

Sementara itu, bentuk-bentuk penyakit sosial pun bermacam-macam. Beberapa penyakit sosial yang bisa ditemukan di masyarakat antara lain sebagai berikut (http://www.crayonpedia.org/).

1. Minuman Keras (Miras). Minuman keras adalah minuman yang memiliki kandungan alkohol lebih dari 5 persen. Keberadaan miras di Indonesia sangat dibatasi oleh aturan pemerintah. Orang-orang yang menyalahgunakan miras akan dikenai sanksi. Adapun yang dimaksud penyalahgunaan di sini adalah suatu bentuk pemakaian yang tidak sesuai dengan ambang batas kesehatan. Artinya, pada dasarnya minuman keras boleh digunakan sejauh hanya untuk maksud pengobatan atau kesehatan di bawah pengawasan dokter atau ahlinya. Di beberapa daerah di Indonesia, terdapat jamu atau minuman tradisional yang dapat digolongkan sebagai minuman keras. Sebenarnya, jika tidak digunakan secara berlebihan, jamu atau minuman tradisional yang dapat digolongkan sebagai minuman keras tersebut, dapat bermanfaat bagi tubuh. Namun, sangat disayangkan jika jamu atau minuman tradisional tersebut, dikonsumsi secara berlebihan atau sengaja digunakan untuk mabuk-mabukan. Para pemabuk minuman keras dapat dianggap sebagai penyakit masyarakat. Para pemabuk biasanya sudah kehilangan rasa malunya, tindakannya tidak terkontrol, dan sering kali melakukan hal-hal yang melanggar aturan masyarakat atau aturan hukum. Minuman keras juga berbahaya jika dikonsumsi saat mengemudi, karena dapat merusak konsentrasi sehingga dapat menimbulkan kecelakaan. Pada pemakaian jangka panjang, tidak jarang para pemabuk minuman keras meninggal dunia karena organ lambung atau hatinya rusak akibat efek samping alkohol yang dikonsumsinya.

2. Penyalahgunaan Narkotik. Pada awalnya, narkotik digunakan untuk keperluan medis, terutama sebagai bahan campuran obat-obatan dan berbagai penggunaan medis lainnya. Narkotik banyak digunakan dalam keperluan operasi medis, karena narkotik memberikan efek nyaman dan dapat menghilangkan rasa sakit sementara waktu, sehingga pasien dapat dioperasi tanpa merasa sakit. Pada pemakaiannya di bidang medis, dibutuhkan seorang dokter ahli untuk mengetahui kadar yang tepat bagi manusia, karena obat-obatan yang termasuk narkotik memunyai efek ketergantungan bagi para pemakainya. Penggunaan narkotik secara sembarangan/tanpa memerhatikan dosis penggunaan inilah yang 
memberikan dampak buruk. Sejak zaman globalisasi, di Indonesia sendiri, sudah banyak orang yang jatuh dalam penyalahgunaan narkoba. Pemakaiannya pun dilakukan dengan berbagai cara, misalnya dihirup asapnya, dihirup serbuknya, disuntikkan, atau ditelan dalam bentuk pil atau kapsul. Padahal, dengan mengonsumsi narkoba, si pengguna bisa menjadi kecanduan. Jika sudah kecanduan, pemakaian narkoba bisa merusak sistem saraf manusia, bahkan dapat menyebabkan kematian. Berikut adalah contoh zat-zat yang termasuk dalam kategori narkotik.

3. Perkelahian Antarpelajar. Perkelahian antarpelajar sering terjadi di kota-kota besar seperti Jakarta, Surabaya, dan kota-kota besar lainnya. Perkelahian tersebut tidak hanya menggunakan tangan kosong atau perkelahian satu lawan satu, melainkan perkelahian bersenjata. Bahkan ada yang menggunakan senjata tajam dan dilakukan secara berkelompok. Banyak korban berjatuhan, bahkan ada yang meninggal dunia. Lebih disayangkan lagi, kebanyakan korban perkelahian tersebut adalah mereka yang justru tidak terlibat perkelahian secara langsung. Mereka umumnya hanya sekadar lewat atau hanya karena salah sasaran pengeroyokan. Kondisi ini jelas sangat mengganggu dan membawa dampak psikis dan traumatis bagi masyarakat, khususnya kalangan pelajar. Pada umumnya mereka menjadi was-was, sehingga kreativitas mereka menjadi terhambat. Hal ini tentu saja membutuhkan perhatian dari semua kalangan, sehingga dapat tercipta suasana yang nyaman dan kondusif khususnya bagi masyarakat usia sekolah.

4. Perilaku Seks di Luar Nikah. Perilaku seks di luar nikah selain ditentang oleh normanorma sosial, juga secara tegas dilarang oleh agama. Perilaku menyimpang ini dilakukan oleh laki-laki dan perempuan yang belum atau bahkan tidak memiliki ikatan pernikahan resmi. Dampak negatif dari perilaku seks di luar nikah, antara lain: lahirnya anak di luar nikah, terjangkit PMS (penyakit menular seksual), bahkan HIV/AIDS, dan turunnya moral para pelaku.

5. Berjudi. Berjudi merupakan salah satu bentuk penyimpangan sosial. Berjudi adalah cara mempertaruhkan harta atau nafkah yang seharusnya dapat dimanfaatkan. Seseorang yang gemar berjudi, akan menjadi malas dan hanya berangan-angan mendapatkan banyak uang dengan cara-cara yang sebenarnya belum pasti. Indonesia merupakan salah satu negara yang melarang adanya perjudian, sehingga seluruh kegiatan perjudian di Indonesia adalah kegiatan ilegal yang dapat dikenai sanksi hukum. Akan tetapi, dalam beberapa kasus, aparat keamanan masih menoleransi kegiatan perjudian yang berkedok budaya, misalnya perjudian yang dilakukan masyarakat saat salah seorang warganya memunyai hajat. Langkah ini sebenarnya kurang tepat, mengingat bagaimanapun juga hal ini tetap merupakan bentuk perjudian yang dilarang agama.

6. Kejahatan (Kriminalitas). Kejahatan adalah tingkah laku yang melanggar hukum dan melanggar norma-norma sosial, sehingga masyarakat menentangnya. Secara yuridis formal, kejahatan adalah bentuk tingkah laku yang bertentangan dengan moral kemanusiaan (amoral), merugikan masyarakat, sifatnya asosiatif, dan melanggar hukum/undang-undang pidana. Tindak kejahatan bisa dilakukan oleh siapa pun baik 
wanita maupun pria, dapat berlangsung pada usia anak, dewasa, maupun usia lanjut. Tindak kejahatan pada umumnya terjadi pada masyarakat yang mengalami perubahan kebudayaan yang cepat, yang tidak dapat diikuti oleh semua anggota masyarakat, sehingga tidak terjadi penyesuaian yang sempurna. Selain itu, tindak kejahatan bisa muncul karena adanya tekanan mental atau kepincangan sosial. Oleh karena itu, tindak kejahatan (kriminalitas) sering terjadi pada masyarakat yang dinamis seperti di perkotaan. Tindak kejahatan (kriminalitas) mencakup pembunuhan, penjambretan, perampokan, korupsi, dan lain-lain.

\section{Metode Jigsaw}

Model berasal dari Bahasa Yunani "Methodos" yang berarti cara atau jalan yang ditempuh. Fungsi model berarti sebagai alat untuk mencapai tujuan. Pengetahuan tentang model-model sangat diperlukan oleh para pendidik, karena berhasil tidaknya siswa belajar sangat bergantung kepada tepat tidaknya model mengajar yang yang digunakan oleh guru. Modelmengajar mampu membangkitkan motivasi, minat atau gairah belajar siswa bahkan mampu meningkatkan hasil belajar siswa.

Menurut Kamus Besar Bahasa Indonesia (2008:740) model adalah cara teratur yang digunakan untuk melaksanakan suatu pekerjaan agar tercapai sesuai dengan yang dikehendaki. Menurut Sudjana dalam Adang Heriawan dkk (2012:73) model mengajar adalah cara yang dipergunakan guru dalam mengadakan hubungannya dengan siswa pada saat berlangsungnya pengajaran, peranan model mengajar sebagai alat untuk menciptakan proses mengajar dan belajar.

Dari beberapa pendapat di atas dapat disimpulkan bahwa model adalah cara yang digunakan oleh seseorang dalam melaksanakan suatu pekerjaan. Dalam hal ini adalah caracara yang dilakukan oleh guru dan peserta didik dalam melaksanakan kegiatan pembelajaran sesuai dengan tujuan yang diharapkan.

Cooperative Learning adalah salah satu model pembelajaran berbasis teori belajar sosial Robert Bandura yang dipopulerkan oleh Spencer Kagan, Robert Slavin dan Johnson \& Johnson. Cooperative Learning adalah model pembelajaran yang menekankan kepada proses kerja sama dalam suatu kelompok yang biasa terdiri dari 3 sampai 5 orang siswa untuk mempelajari suatu materi akademik yang spesifik sampai tuntas. (Adang Heriawan dkk, 2012:109). Menurut Slavin dalam Isjoni (2010 : 12) Cooperative Learning adalah model pembelajaran dimana siswa belajar dan bekerja dalam kelompok-kelompok kecil secara kolaboratif yang anggotanya 4-6 orang dengan struktur kelompok heterogen. Inti dari pembelajaran kooperatif menurut Robert E.Slavin yang diterjemahkan oleh Narulita Yusron (2010: 8) "Dalam model pembelajaran kooperatif, para siswa akan duduk bersama dalam kelompok yang beranggotakan empat orang untuk menguasai materi yang disampaikan oleh guru." Menurut Johnson \& Johnson dalam Isjoni (2010:17) Cooperataive Learning adalah mengelompokkan siswa di dalam kelas ke dalam suatu kelompok kecil agar siswa dapat bekerja bersama dengan kemampuan maksimal yang mereka miliki dan mempelajari satu sama lain dalam kelompok tersebut. 
Dari beberapa definisi di atas dapat disimpulkan bahwa Model Cooperatif Learning adalah salah satu model pembelajaran yang mengutamakan kerjasama kelompok dalam menyelesaikan materi pembelajaran, memecahkan masalah atau menyelesaikan sebuah tujuan. Ada beberapa model dalam model pembelajaran Cooperative Learning diantaranya adalah: Jigsaw, Student Team Achievement Division (STAD), Team Game Tornament (TGT), Number Head Together (NHT), Group Investigation, Team Assisted Individualization (TAI)

Pembelajaran Kooperatif JIGSAW merupakan salah satu tipe pembelajaran kooperatif yang mendorong siswa aktif dan saling membantu dalam menguasai materi pelajaran untuk mencapai prestasi yang maksimal dengan cara membentuk tim ahli. Dalam model ini terdapat tahap-tahap dalam penyelenggaraannya, yaitu:

1) Pembentukan kelompok siswa yang terdiri dari 4-6 orang secara heterogen.

2) Setiap anggota dalam kelompok ditugaskan untuk mempelajari materi tertentu.

3) Setiap anggota kelompok yang mempelajari materi yang sama bertemu dalam satu kelompok baru membentuk 'Tim Ahli'. Selanjutnya materi tersebut didiskusikan, dipelajari apabila menemukan masalah dibahas bersama.

4) Setelah masing-masing perwakilan dalam tim ahli tersebut dapat menguasai materi yang ditugaskannya, kemudian masing-masing perwakilan tersebut kembali ke kelompok masing-masing atau kelompok asalnya dan mengajarkan pada temannya.

5) Masing-masing anggota tersebut saling menjelaskan kepada teman satu kelompoknya sehingga teman dalam satu kelompoknya dapat memahami materi yang ditugaskan guru.

6) Setiap kelompok mempresentasikan hasil diskusi.

7) Siswa diberi tes/kuis untuk mengetahui apakah siswa sudah dapat memahami suatu materi atau belum.

Dengan demikian melalui penyelenggaraan model Jigsaw dalam proses belajar mengajar dapat menumbuhkan tanggung jawab siswa sehingga terlibat langsung secara aktif dalam memahami suatu persoalan dan menyelesaikannya secara kelompok.

Pada kegiatan ini ini keterlibatan guru dalam belajar mengajar semakin berkurang. dalam arti guru tidak lagi menjadi pusat kegiatan kelas. Guru berperan sebagai fasilitator yang mengarahkan dan memotivasi siswa untuk belajar mandiri serta menumbuhkan rasa tanggung jawab serta siswa akan merasa senang berdiskusi tentang materi pelajaran dalam kelompoknya.

Model Jigsaw sangat cocok untuk mata pelajaran IPS karena dalam IPS banyak materi naratifnya, seperti yang dikemukakan oleh Isjoni (2010:58) model Jigsaw dapat digunakan secara efektif di tiap level dimana siswa telah mendapatkan keterampilan akademis dari pemahaman, membaca maupun keterampilan kelompok untuk belajar bersama, jenis materi yang paling mudah digunakan untuk pendekatan ini adalah bentuk naratif seperti ditemukan dalam literatur, penelitian sosial membaca, dan ilmu pengetahuan. 


\section{Ilmu Pengetahuan Sosial}

Ilmu Pengetahuan Sosial (IPS) yaitu salah satu mata pelajaran yang diajarkan di Sekolah Menengah Pertama yang disampaikan secara terpadu, terdiri dari materi pelajaran Geografi, Sejarah, Ekonomi, dan Sosiologi. Materi Ilmu Pengetahuan Sosial ini memiliki beban belajar sebanyak 4 jam pelajaran dalam satu minggu dengan waktu 40 menit setiap jam pelajaran.

Memahami masalah Penyimpangan Sosial. Materi pelajaran yang digunakan dalam penelitian tindakan kelas ini adalah: Berbagai penyakit sosial sebagai akibat penyimpangan sosial dalam keluarga dan masyarakat, merupakan salah satu pokok bahasan mata pelajaran Ilmu Pengetahuan Sosial termasuk dalam kajian Geografi yang diberikan pada semester gasal, dengan keterangan sebagai berikut: SK:3. Memahami Masalah Penyimpangan Sosial. KD: 3.1 Mengidentifikasi berbagai penyakit sosial (Miras, judi, narkoba, HIV/AIDS, PSK, dan lain-lain) sebagai akibat penyimpangan sosial dalam keluarga dan masyarakat.

\section{METODE}

Metode penelitian menggunakan penelitian tindakan kelas (PTK) yang dilaksanakan dalam dua siklus setiap siklus terdiri dua kali pertemuan, dengan empat tahap penelitian: perencanaan, pelaksanaan, pengamatan dan refleksi. Subjek penelitian ini adalah siswa-siswi kelas VIII B SMP Negeri 6 Sukoharjo tahun ajaran 2017/2018. Dengan jumlah 22 siswa. Teknik pengumpulan data yang digunakan adalah observasi, wawancara, tes, dan dokumentasi. Analisis data yang digunakan dalam penelitian ini adalah analisis deskriptif kualitatif.

\section{PEMBAHASAN}

Setelah peneliti melaksanakn tindakan penelitian melalui penerapan metode Jigsaw, secara empiris diperoleh data peningkatan prestasi belajar IPS Geografi siswa kelas VIII B SMP Negeri 6 Sukoharjo Kecamatan Sukoharjo, Kabupaten Sukoharjo semester I Tahun Pelajaran 2017/2018 dari kondisi awal, siklus I dan siklus II sebagai berikut.

Tabel 1. Peningkatan Prestasi Belajar Siswa

\begin{tabular}{|c|c|c|c|}
\hline Uraian & Kondisi awal & Siklus I & Siklus II \\
\hline $\begin{array}{c}\text { Tindakan } \\
\text { Pembelajaran }\end{array}$ & $\begin{array}{l}\text { Belum menerapkan } \\
\text { metode Jigsaw }\end{array}$ & $\begin{array}{c}\text { Sudah menerapkan metode } \\
\text { Jigsaw }\end{array}$ & $\begin{array}{c}\text { Sudah menerapkan metode } \\
\text { Jigsaw }\end{array}$ \\
\hline Nilai terendah & 60 & 60 & 70 \\
\hline Nilai tertinggi & 80 & 90 & 90 \\
\hline Nilai rata-rata & 73 & 77 & 83 \\
\hline KKM & 75 & 75 & 75 \\
\hline Ketuntasan & 12 siswa $(54.54 \%)$ & 14 siswa $(63.63 \%)$ & 18 siswa $(81.81 \%)$ \\
\hline
\end{tabular}


Melalui penerapan metode Jigsaw dapat meningkatkan prestasi belajar IPS Geografi materi mengidentifikasi berbagai penyakit sosial sebagai akibat penyimpangan sosial dalam keluarga dan masyarakat.

Pada kondisi awal peneliti belum menerapkan metode Jigsaw. Nilai rata-rata siswa kelas VIII B adalah 73, masih di bawah nilai KKM yang ditetapkan yaitu 75. Nilai tertinggi siswa 80, nilai terendah 60 dan jumlah siswa kelas VIII B yang mencapai nilai KKM hanya 12 siswa (54.54\%) dari total 22 siswa kelas VIII B SMP Negeri 6 Sukoharjo.

Pada siklus I guru peneliti sudah menerapkan metode Jigsaw dalam pembelajaran IPS Geografi materi mengidentifikasi berbagai penyakit sosial sebagai akibat penyimpangan sosial dalam keluarga dan masyarakat. Nilai rata-rata prestasi belajar IPS Geografi siswa kelas VIII B SMP Negeri 6 Sukoharjo adalah 77, nilai tertinggi 90 dan nilai terendah adalah 60. Sedangkan jumlah siswa yang mencapai nilai KKM sebanyak 14 siswa (63.63\%) dari total 22 siswa kelas VIII B SMP Negeri 6 Sukoharjo.

Pada siklus II, nilai rata-rata prestasi belajar IPS Geografi siswa kelas VIII B SMP Negeri 6 Sukoharjo adalah 83, nilai tertinggi 90 dan nilai terendah 70. Jumlah siswa yang mencapai nilai KKM sebanyak 18 siswa $(81.81 \%)$ dari total 22 siswa kelas VIII B SMP Negeri 6 Sukoharjo.

Jadi, melalui penerapan metode Jigsaw dapat meningkatkan prestasi belajar IPS Geografi materi mengidentifikasi berbagai penyakit sosial sebagai akibat penyimpangan sosial dalam keluarga dan masyarakat dari kondisi awal nilai rata-rata 73 dengan ketuntasan $54.54 \%$ ke kondisi akhir pada siklus II nilai rata-rata 83 dengan ketuntasan $81.81 \%$ pada siswa kelas VIII B SMP Negeri 6 Sukoharjo semester I Tahun Pelajaran 2017/2018.

Hasil tindakan secara empirik yaitu: melalui penerapan metode Cooperative Learning Jigsaw dapat meningkatkan prestasi belajar IPS Geografi materi mengidentifikasi berbagai penyakit sosial sebagai akibat penyimpangan sosial dalam keluarga dan masyarakat dari kondisi awal nilai rata-rata 73 dengan ketuntasan $54.54 \%$ ke kondisi akhir pada siklus II nilai rata-rata 83 dengan ketuntasan $81.81 \%$ pada siswa kelas VIII B SMP Negeri 6 Sukoharjo semester I Tahun Pelajaran 2017/2018.

\section{SIMPULAN}

Hipotesis menyatakan diduga melalui penerapan metode Cooperative Learning Jigsaw dapat meningkatkan prestasi belajar IPS Geografi materi mengidentifikasi berbagai penyakit sosial sebagai akibat penyimpangan sosial dalam keluarga dan masyarakat pada siswa kelas VIII B SMP Negeri 6 Sukoharjo semester I Tahun Pelajaran 2017/2018.

Dari data empirik menyatakan melalui penerapan metode Cooperative Learning Jigsaw dapat meningkatkan prestasi belajar IPS Geografi materi mengidentifikasi berbagai penyakit sosial sebagai akibat penyimpangan sosial dalam keluarga dan masyarakat dari kondisi awal nilai rata-rata 73 dengan ketuntasan $54.54 \%$ ke kondisi akhir pada siklus II nilai rata-rata 83 dengan ketuntasan $81.81 \%$ pada siswa kelas VIII B SMP Negeri 6 Sukoharjo semester I Tahun Pelajaran 2017/2018. 
Sehingga dapat disimpulkan bahwa melalui penerapan metode Cooperative Learning Jigsaw dapat meningkatkan prestasi belajar IPS Geografi materi mengidentifikasi berbagai penyakit sosial sebagai akibat penyimpangan sosial dalam keluarga dan masyarakat pada siswa kelas VIII B SMP Negeri 6 Sukoharjo semester I Tahun Pelajaran 2017/2018.

\section{DAFTAR PUSTAKA}

Ahmadi, Abu. 1998. Psikologo Pendidikan. Jakarta: Rineka Cipta

Agus, Suprijono. 2011. Model Pembelajaran Kooperatif. Jakarta: Bumi Aksara

Dimyati dan Mudjiono. 2006. Belajar dan Pembelajaran. Jakarta: Rineka Cipta

Heriawan, Adang dkk. 2012. Metodologi Pembelajaran Kajian Teoritis Praktis

Ismail 2011. Manajemen Perbankan. Jakarta: Prenada Media Group

Isjoni. 2010. Cooperative Learning Efektifitas Pembelajaran Kelompok. Bandung: Alfabeta

Muhibbin Syah.1999.Psikologi Pendidikan Dengan Pendekatan Baru.Bandung:PT Remaja Rosdakarya

M. Sobry Sutikno. 2010. Strategi Belajar Mengajar Melalui Penanaman Konsep Umum \& Konsep Islami. Refika Aditama: Bandung.

Nasution. 1995. Metode Research. Jakarta : PT. Bumi Aksara

Ngalim Purwanto. 1986. Psikologi Pendidikan. Bandung: PT Remaja Rosdakarya.

Ngalim Purwanto. 2008. Metodologi Penelitian Kuantitatif. Yogyakarta: Pustaka Pelajar

Sardjiyo. 2010. Pendidikan IPS di SD. Jakarta: Universitas Terbuka

Slameto. 2000. Belajar dan Faktor-faktor yang mempengaruhinya. Rineka Cipta,Jakarta

Teti Sobari. 2006. Pembelajaran Kooperatif. Jakarta: PT. Bumi Aksara

Tho'in, M. (2017). Pembiayaan Pendidikan Melalui Sektor Zakat. Al-Amwal: Jurnal Ekonomi dan Perbankan Syari'ah, 9(2).

Winkel, W. S. 2004. Psikologi Pendidikan dan Evaluasi Belajar. Jakarta: PT. Gramedia Pustaka Utama.

Web: http://www.crayonpedia.org/ diakses 20 Desember 2017 